\title{
PELATIHAN BUDIDAYA DAN PEMASARAN IKAN CUPANG UNTUK MENGATASI MASALAH EKONOMI DI MASA PANDEMI
}

\author{
Erwan Setiawan $^{1}$, Ramdhan F. Suwarman ${ }^{2}$, Andri Firmansyah ${ }^{3}$, M. Dodi Saputra ${ }^{4}$ \\ ${ }^{1,2,3,4}$ Universitas Suryakancana \\ ${ }^{1}$ korespondensi : erwan@unsur.ac.id
}

\begin{abstract}
ABSTRAK
Pandemi COVID-19 memberikan dampak yang serius di sektor ekonomi. Sekitar 47 persen UMKM berhenti usaha diakibatkan turunnya omset penjualan. Berbeda dengan bidang ekonomi lain yang mengalami penurunan omset, bisnis ikan cupang hias mencatatkan hal sebaliknya. Peningkatan omset mencapai $70 \%$ dirasakan para peternak ikan cupang hias selama pandemi ini. Mengingat akhir pandemi yang tidak bisa diprediksi maka jenis bisnis ini sangat menarik untuk dicoba oleh masyarakat. Permasalahan utama yang muncul adalah minimnya pengetahuan masyarakat akan ikan cupang hias. Maka pemberian pelatihan budidaya ikan cupang hias dan cara pemasarannya menjadi solusi yang sangat efektif. Kegiatan pelatihan dilakukan langsung di lokasi peternak ikan cupang hias yang ada di Cianjur agar masyarakat mudah menyerap materi yang disampaikan. Selain memberikan materi pelatihan, masyarakat juga dibekali sepasang indukan ikan cupang hias sebagai modal untuk mencoba melakukan budidaya di rumah masing-masing. Hasilnya beberapa masyarakat sudah dapat melakukan budidaya sampai dengan tahap menetaskan telur ikan cupang hias, sedangkan untuk pembesaran masih memerlukan waktu yang lebih lama sekitar 3 bulan. Kesimpulan yang dapat diambil dari kegiatan ini adalah budidaya ikan cupang hias ini dapat memberikan alternatif usaha tambahan guna menambah pendapatan masyarakat dan melalui budidaya ini beberapa jenis usaha baru yang berkaitan dengan ikan cupang hias menjadi bermunculan.
\end{abstract}

Kata Kunci: Ikan Cupang, Budidaya Ikan Cupang

\begin{abstract}
The COVID-19 pandemic has had a serious impact on the economic sector. About 47 percent of UMKM quit their business due to decreased income. The opposite is found in the betta fish business. Betta fish farmers have felt an increase in income of up to $70 \%$ during this pandemic. Given the unpredictable end of the pandemic, this type of business is very interesting for the public to try. The main problem that arises is the lack of public knowledge about betta fish. So providing training in betta fish breeding and how to market it is a very effective solution. Training activities are carried out directly at the location of betta fish breeders in Cianjur so that people can easily absorb the material presented. In addition to providing training materials, the community is also equipped with a pair of betta fish that are ready to be bred as capital to try breeding in their homes. As a result, some of the training participants have been able to breed until the stage of hatching betta fish eggs, while for enlargement it still takes a longer time, around 3 months. The conclusion that can be drawn from this activity is that the breeding of betta fish can provide additional business alternatives to increase people's income and through this cultivation several new types of business related to betta fish have emerged.
\end{abstract}

Keywords: Betta Fish, Betta Fish Breeding.

\section{PENDAHULUAN}

Pandemi COVID-19 yang dirasakan hampir di seluruh negara memiliki dampak yang luar biasa. Tidak hanya sektor kesehatan, sektor ekonomi juga mengalami dampak yang serius akibat pandemi ini. Di Indonesia, COVID-19 telah membuat sektor ekonomi mengalami perlambatan pertumbuhan. Bahkan menurut Laporan Badan Statistik (BPS), pertumbuhan ekonomi pada kuartal II 2020 minus 5,32 persen. Kinerja ekonomi yang melemah ini 
turut pula berdampak pada situasi ketenagakerjaan di Indonesia.

Berdasarkan data Kemnaker per 1 Mei 2020, jumlah pekerja sektor formal yang telah dirumahkan akibat pandemi COVID-19 sebanyak 1.032 .960 orang dan pekerja sektor formal yang di-PHK sebanyak 375.165 orang. Sedangkan pekerja sektor informal yang terdampak COVID-19 sebanyak 314.833 orang. Total pekerja sektor formal dan informal yang terdampak COVID-19 sebanyak 1.722 .958 orang [1].

Nasib UMKM pun tak jauh berbeda. Menteri Koperasi dan UMKM Teten Masduki menjelaskan bahwa pelaku UMKM pada saat ini harus menghadapi masalah yang cukup besar. "Diramalkan survei 47 persen UMKM berhenti berusaha, kami juga mencatat hal yang sama," katanya dalam diskusi virtual yang digelar Himpuni pada Rabu, 20 Mei 2020 [2].

Di tengah tren penurunan omset yang dirasakan hampir semua bidang di sektor ekonomi, ternyata bisnis ikan hias menunjukkan tren sebaliknya. Terutama jenis ikan cupang hias. Andri peternak ikan cupang hias di Cianjur mengatakan bahwa selama pandemi ini penjualan ikan cupang hias mengalami peningkatan omset mencapai 70 persen. Peternak lain di daerah Bogor yaitu Rizal merasakan hal yang sama. Peningkatan omset penjualan ikan cupang hias mencapai 80 persen selama pandemi ini [3].

Seperti kita ketahui bahwa di masa pandemi ini, sebagian besar masyarakat dianjurkan untuk tetap berdiam diri di rumah agar terhidar dari penularan virus Covid-19 [4]. Tentu saja sebagai makhuk hidup, sebagian besar masyarakat akan cenderung untuk mencari cara agar tidak jenuh selama berdiam diri di rumah. Salah satu cara yang dilakukan adalah melalui memelihara binatang, tumbuhan, atau hobi lainnya. Maka tak heran, pada situasi saat ini penjualan berbagai binatang peliharaan atau tumbuhan meningkat dengan pesat, tak terkecuali penjualan ikan cupang hias.

Fenomena ini tentunya harus dimanfaatkan sebaik mungkin mengingat belum adanya kepastian waktu berakhirnya pandemi ini. Universitas Suryakancana sebagai perguruan tinggi terbesar di Cianjur melalui kegiatan Kuliah Kerja Nyata Kewirausahaan merespon fenomena ini dengan memberikan pelatihan budidaya ikan cupang hias pada masyarakat khususnya di desa Hegarmanah kabupaten Cianjur.

Di masa pandemi ini, tentunya masyarakat akan lebih memilih menggunakan uangnya untuk keperluan sehari-hari daripada untuk mencoba membuka jenis usaha baru. Sehingga apabila ada tawaran jenis usaha baru dalam bidang apapun akan sangat susah untuk dapat diterima, apalagi jika jenis usaha tersebut memerlukan modal yang cukup besar.

Kenapa memilih budidaya ikan cupang hias? Kegiatan usaha ikan hias memiliki beberapa keunggulan komparatif, di antaranya bisa dengan modal yang sedikit, dapat dilakukan oleh industri rumah tangga, pasarnya tidak pernah jenuh, pengembangan strain baru dapat dilakukan secara indvidu, dan kegiatan usaha 
ini dapat memberdayakan masyarakat melalui industri kecil yang bermuara pada ekspor [5].

Ikan cupang merupakan salah satu jenis ikan hias yang tidak memerlukan modal besar baik dalam pemeliharaan maupun dalam pembudidayaan. Budidaya ikan cupang tidak memerlukan tempat luas dan bisa dilakukan sebagai usaha rumahan dengan lahan yang sempit (seadanya) [6]

Gambaran singkat terkait budidaya ikan cupang adalah sebagai berikut: wadah pemijahan induk yang digunakan terbuat dari plastik berbentuk silinder dan berdiameter 20 $\mathrm{cm}$. Wadah tersebut diisi dengan air hingga mencapai ketinggian $\pm 15 \mathrm{~cm}$. Perbandingan antara induk jantan dan betina yang digunakan dalam pemijahan adalah 1:1. Induk jantan terlebih dahulu dimasukkan ke dalam wadah pemijahan, selanjutnya induk betina dimasukkan ke botol bekas air mineral dan diletakkan di tengah-tengah wadah pemijahan. Setelah induk jantan membuat gelembung udara, induk betina dilepaskan ke dalam wadah pemijahan [7].

Dalam segi pemeliharaanpun, ikan cupang termasuk ikan yang tidak susah dalam hal jenis pakannya. Berdasarkan survei yang telah dilakukan pada beberapa toko ikan hias dan pembudidaya ikan Cupang di Yogyakarta, diketahui ada dua jenis pakan yang biasa digunakan yaitu pakan alami dan buatan. Pakan buatan yang dimaksud adalah pakan dalam bentuk pellet, sementara pakan alami yang biasa digunakan diantaranya jentik nyamuk, Moina sp. atau yang dikenal masyarakat dengan kutu air dan cacing darah yang tidak lain adalah larva Chironomus sp [9]

Dengan dasar ini, tentu budidaya ikan cupang hias akan menjadi menarik bagi masyarakat untuk coba dilakukan. Tujuan dari pelatihan budidaya ikan cupang hias ini memberikan wawasan kepada masyarakat terkait masalah pemeliharaan, budidaya, dan pemasaran ikan cupang hias. Adapun peserta yang mewakili Universitas Suryakancana untuk memberikan pelatihan adalah

Dosen Pembimbing:

1. Erwan Setiawan, S.Si., M.Si.

2. Ramdhan F. Suwarman

Mahasiswa:

1. Andri Firmansyah

2. Muhammad Dodi Saputra

\section{METODE}

Pengetahuan masyarakat akan ikan cupang hias masih sangat minim, sebagian besar masyarakat menganggap ikan cupang merupakan ikan mainan anak-anak sekolah dasar yang sering dipakai untuk ditarungkan/di-adu-kan. Hal ini tentu tidak sepenuhnya salah karena sejatinya ikan cupang merupakan ikan petarung yang akan mudah bertarung jika bertemu dengan ikan cupang lainnya. Akan tetapi pemahaman ini pun tidak sepenuhnya benar, karena saat ini ikan cupang sudah sangat berkembang baik dari jenis, warna, dan harga. 
Tidak hanya sebagai ikan aduan, tetapi ikan cupang juga dapat dijadikan sebagai ikan hias yang sangat cantik. Dari sisi ekonomi, ikan cupang hias pun menawarkan prospek yang sangat menggiurkan karena seekor ikan cupang hias dapat berharga hingga puluhan juta rupiah tergantung dari jenis dan kecantikan ikan cupang hias itu sendiri.

Seberapa jauh pengetahuan masyarakat akan ikan cupang hias ini tentu akan berpengaruh terhadap seberapa besar minat masyarakat untuk membudidayakan ikan ini. Selain pengetahuan yang minim dari ikan cupang hias, masalah lain yang dihadapi adalah masalahpemasaran dan masalah pengadaan pakan alami bagi ikan, terutama pakan jenis kutu air.

Salah satu cara yang paling efektif untuk memberikan pemahaman pada masyarakat adalah melalui pelatihan dan mengajak masyarakat untuk terjun langsung melihat peternak ikan cupang hias yang sudah ada di desa Hegarmanah kecamatan Karang Tengah Cianjur. Mengingat situasi saat ini yang sedang pandemi COVID-19, maka kegiatan kunjungan pun hanya melibatkan beberapa pemuda-pemuda yang cukup tertarik untuk mencoba melakukan budidaya ikan cupang hias.

Diharapkan melalui pemuda-pemuda ini, berbagai informasi berkaitan dengan ikan cupang hias ini akan sampai pada masyarakat, sehingga pada akhirnya budidaya ikan cupang hias ini dapat menjadi salah satu alternatif kegiatan usaha bagi masyarakat untuk menambah pendapatan rumah tangganya.
Beberapa hal yang perlu diperhatikan dalam melakukan budidaya ikan cupang adalah

1. Manajemen pengadaan benih ikan cupang

2. Manajemen pemberian pakan ikan cupang

3. Manajemen kesehatan ikan cupang

4. Manajemen kualitas air ikan cupang

5. Manajemen reproduksi ikan cupang [8]

Berdasarkan hal-hal tersebut maka kegiatan pelatihan budidaya yang dilakukan adalah

(a) Memberi pengetahuan cara pemilihan indukan ikan cupang hias yang bagus.

(b) Memberikan pengetahuan cara pembiakan ikan cupang hias yang baik dan benar.

(c) Memberi pengetahuan cara perawatan ikan cupang agar sehat tidak terkena penyakit.

(d) Memberi pengetahuan cara pembiakan pakan alami infusoria untuk burayak (anakan) ikan cupang hias.

(e) Memberi pengetahuan pembiakan kutu air pakan alami untuk ikan cupang hias yang dewasa.

(f) Memberi pengetahuan cara pemasaran ikan cupang hias secara online.

Budidaya ikan cupang hias ini, dari awal pemijahan sampai panen memerlukan waktu sekitar 3 bulan. Sedangkan program KKN Kewirausahaan ini hanya berlangsung selama 1 bulan. Oleh karena itu, apabila tidak ada kendala yang berarti, tim pengabdian akan coba untuk melakukan pendampingan atau pemantauan kepada masyarakat yang sudah diberikan materi pelatihan budidaya dan sepasang indukan ikan cupang hias. Hal ini 
dilakukan agar masyarakat dapat berhasil dalam melakukan budidaya ini.

\section{HASIL DAN PEMBAHASAN}

Proses pelatihan memerlukan waktu kurang lebih 1 minggu dengan uraian kegiatan sebagai berikut:

a) Memberi pengetahuan cara pemilihan indukan ikan cupang hias yang bagus

Dalam kegiatan ini, peserta pelatihan diberikan pengetahuan mengenai beberapa jenis ikan cupang yang ada saat ini, membedakan jenis kelamin ikan cupang, dan cara memberikan pengetahun kualitas ikan cupang yang baik untuk dijadikan indukan.

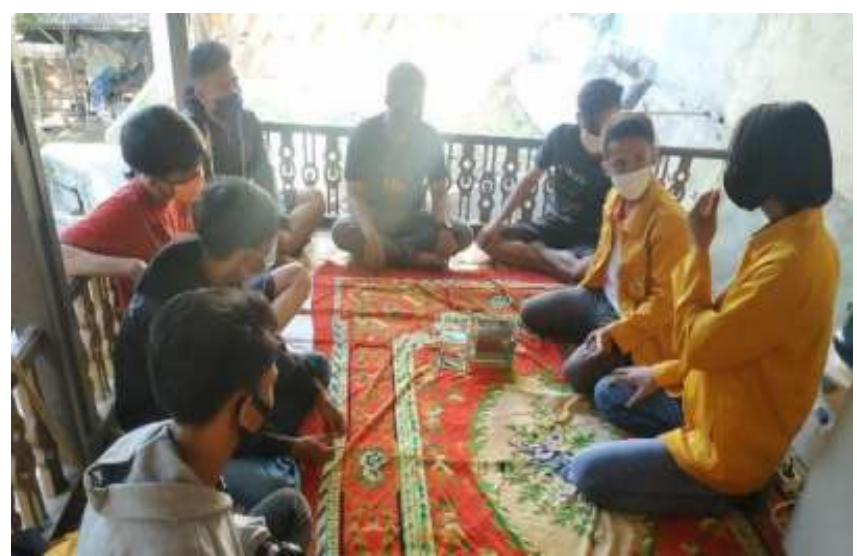

Gambar 1 : Persentasi terkait ikan cupang dan pemilihan indukan ikan cupang

b) Memberikan pengetahuan cara breeding ikan cupang hias yang baik dan benar.

Peserta diajak langsung untuk melihat bagaimana melakukan breeding ikan cupang, dimulai dari penyiapan media pembiakan sampai dengan proses perkawinan dari ikan cupang. Peserta diberikan pengetahuan mengenai hal-hal yang harus dihindari agar proses perkawinan berjalan lancar dan dapat menghasilkan anakan ikan cupang yang maksimal.

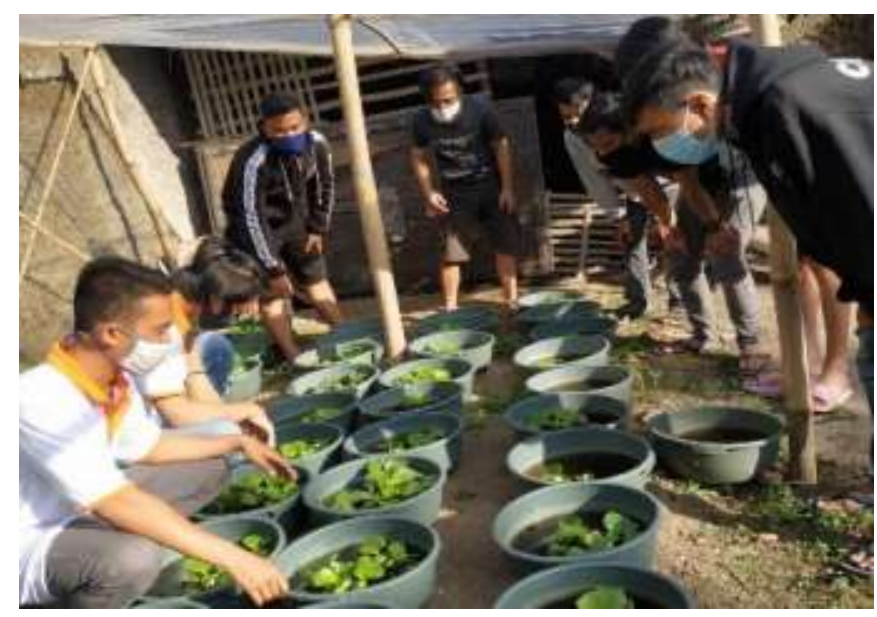

Gambar 2 : Memberikan penjelasan dan contoh cara melakukan pembiakan ikan cupang 
c) Memberi pengetahuan cara perawatan ikan cupang agar sehat tidak terkena penyakit.

Pada kegiatan ini, peserta dibekali cara perawatan ikan cupang mulai dari merawat ikan cupang anakan sampai dengan ikan cupang dewasa. Cara-cara merawat ikan cupang yang terindikasi sakit pun diberikan.

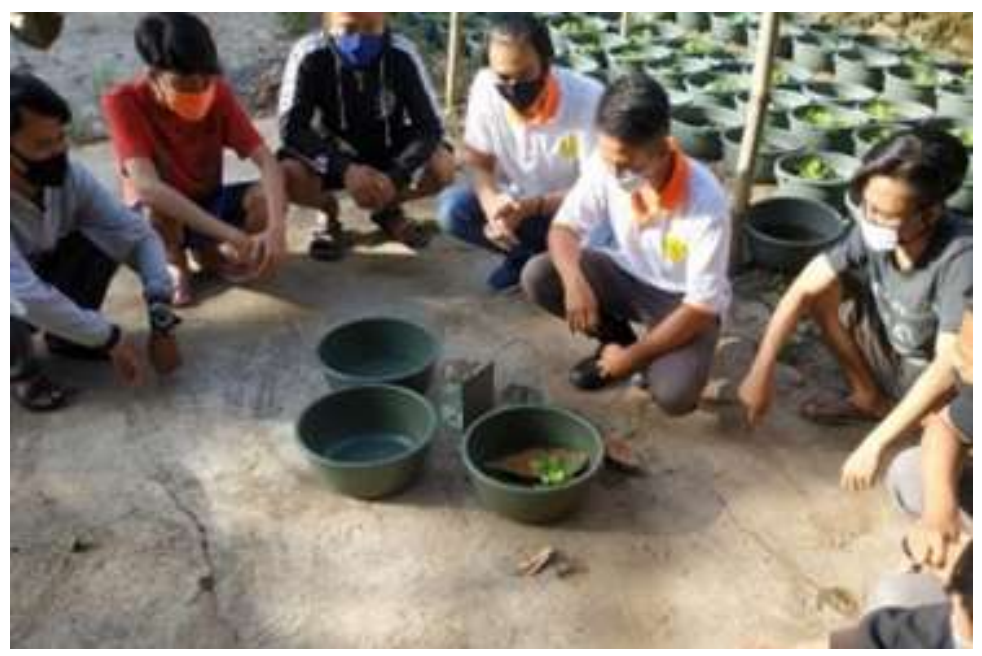

Gambar 3 : Persentasi terkait perawatan ikan cupang

d) Memberi pengetahuan cara kultur (budidaya) pakan alami infusoria untuk burayak (anakan) ikan cupang hias.

Perawatan ikan cupang anakan atau yang lebih dikenal dengan burayak memerlukan perhatian yang ekstra. Ukuran burayak yang masih sangat kecil mengharuskan peternak untuk menyiapkan jenis makanan yang berukuran sangat kecil sehingga dapat dimakan oleh burayak. Pakan yang cocok untuk burayak adalah infusoria, sejenis hewan air yang berukuran sangat kecil sekali. Bagaimana cara menghasilkan infusoria dan membudidayakannya merupakan kegiatan utama dalam tahap ini.

e) Memberi pengetahuan cara kultur (budidaya) kutu air pakan alami untuk ikan cupang hias yang dewasa.
Selain pakan untuk burayak, pakan untuk ikan cupang dewasa pun harus diperhatikan. Dalam tahap ini, peserta dibekali cara membudidayakan kutu air sebagai pakan utama ikan cupang dewasa. Dengan kemampuan ini, diharapkan peserta mampu menekan anggaran pengeluaran untuk pakan ikan ketika nantinya mencoba untuk melakukan budidaya ikan cupang.

f) Memberi pengetahuan cara pemasaran ikan cupang hias secara online.

Dalam kegiatan terakhir adalah membekali peserta pelatihan untuk mengetahui cara pemasaran online. Peserta pelatihan yang sebagian besar pemuda, membuat tahap ini lebih mudah dipahami karena peserta sudah terbiasa dengan penggunaan handphone/gadget. Kelebihan ikan cupang yang dapat hidup dengan baik tanpa aerator 
memungkinkan para peternak cupang maupun negara.

melakukan transaksi lintas kota, provinsi,

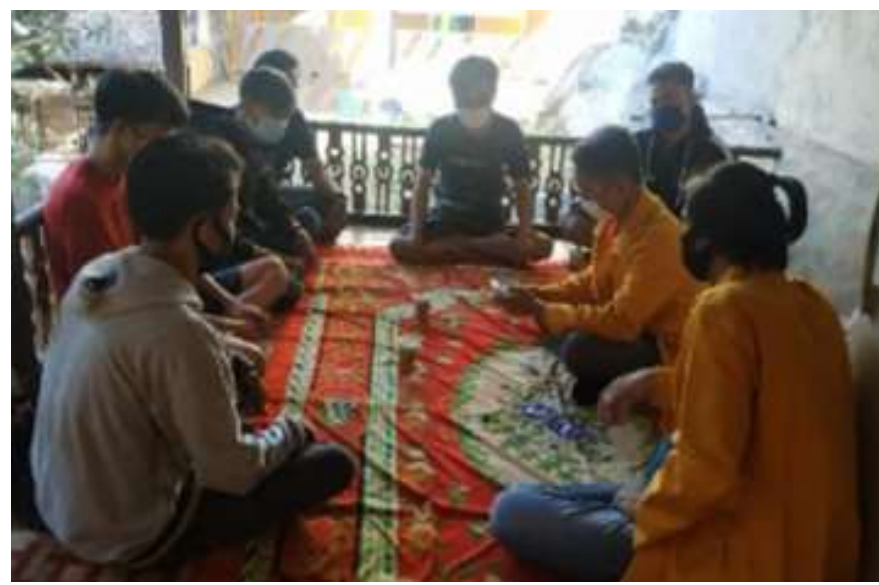

Gambar 4 : Persentasi terkait cara pemasaran ikan cupang secara online

Terdapat dua jenis hasil dari kegiatan ini, yaitu hasil yang berupa fisik dan non-fisik. Hasil fisik yang didapatkan akan terlihat setelah 4 bulan masyarakat melakukan budidaya. Karena setelah berusia 4 bulan, ikan cupang hias siap untuk dipasarkan. Sedangkan hasil non-fisik berupa pengetahuan masyarakat terkait ikan cupang hias, baik dari segi perawatan, budidaya dan pemasaran menjadi lebih meningkat.

Hasil jangka pendek yang dapat dilaporkan berdasarkan survei yang telah dilakukan terhadap masyarakat yang melakukan budidaya adalah

- Adanya antusias masyarakat untuk mencoba melakukan budidaya dengan memanfaatkan area di pekarangan rumah.

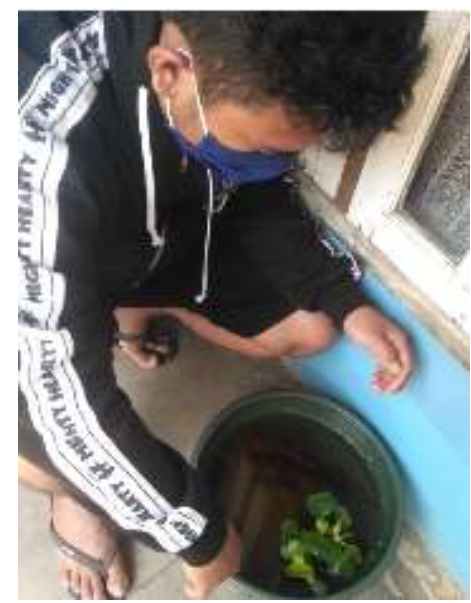

Gambar 5 : Melakukan kegiatan pembiakan ikan cupang

- Mampu melakukan budidaya khususnya pada bagian pemijahan telur ikan cupang sampai dengan menetas. 


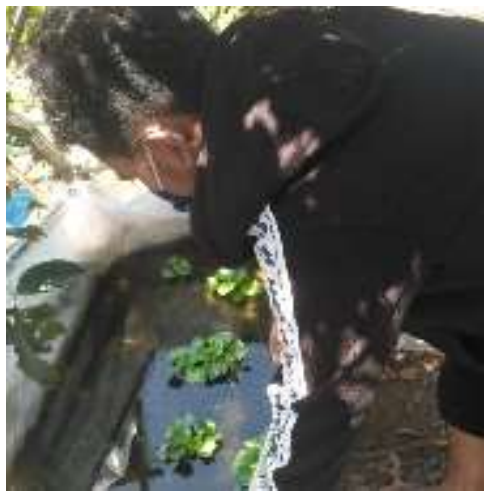

Gambar 6 : Pemindahan burayak ikan cupang ke wadah pembesaran

- Mampu melakukan budidaya pakan alami

bagi ikan cupang hias yang berupa kutu air.

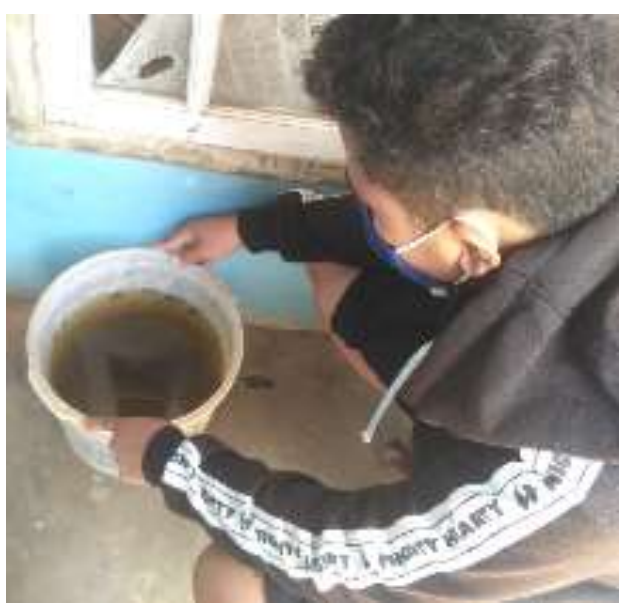

Gambar 7 : Pembiakan kutu air

\section{PENUTUP}

Budidaya ikan cupang hias memberikan alternatif usaha bagi masyarakat untuk menambah perekonomian rumah tangga.

Usaha-usaha penunjang budidaya ikan cupang hias, seperti kultur kutu air, cacing sutra, jentik nyamuk, dsb sebagai pakan alami ikan cupang, akan membuka jenis usaha baru.

\section{DAFTAR PUSTAKA}

[1] J. G. Rizal, "Pandemi Covid-19, Apa Saja Dampak pada Sektor Ketenagakerjaan Indonesia?,"
Kompas,

2020. https://www.kompas.com/tren/read/20 20/08/11/102500165/pandemi-covid19-apa-saja-dampak-pada-sektorketenagakerjaan-indonesia.

[2] F. U. Sofuroh, "Data Kemnaker: Pekerja Terdampak COVID-19 Capai Sekitar 3 Juta Orang," Detik, May 2020. https://finance.detik.com/beritaekonomi-bisnis/d-5009421/datakemnaker-pekerja-terdampak-covid19-capai-sekitar-3-juta-orang.

[3] H. Khatimah, "Bisnis Ikan Cupang di Bogor Kebal Pandemi Covid-19, Omzet Meningkat," AYO BOGOR.COM, Aug. 2020. https://m.ayobogor.com/read/2020/08/ 24/8264/bisnis-ikan-cupang-di-bogor- 
kebal-pandemi-covid-19-omzetmeningkat.

[4] T. Maharani, "Jubir Pemerintah: Tetap Tinggal di Rumah adalah Solusi Terbaik Cegah Penyebaran Covid-19," Kompas, 2020. https://nasional.kompas.com/read/2020 /04/04/17042991/jubir-pemerintahtetap-tinggal-di-rumah-adalah-solusiterbaik-cegah.

[5] E. Kusrini, "Budidaya Ikan Hias Sebagai Pendukung Pembangunan Nasional Perikanan Di Indonesia," Media Akuakultur, vol. 5, no. 2, p. 109, 2010, doi: 10.15578/ma.5.2.2010.109-114.

[6] P. Oto, "Pemanfaatan Lahan Sempit Sebagai Tempat Budidaya Ikan," Aksiologiya J. Pengabdi. Kpd. Masy., vol. 3, no. 2, pp. 113-123, 2019.
[7] Annur, Madinawati, S. F. Mangitung, and Rusaini, "EMBRIOGENESIS IKAN CUPANG ( Betta splendens) THE EMBRYOGENESIS OF SIAMESE FIGHTING FISH (Betta splendens)," J. Agrisains, vol. 17, no. 3, pp. 137-140, 2016.

[8] F. Saputra and T. R. Efianda, "Pelatihan Manajemen Pemeliharaan Ikan Cupang Sebagai Ikan Hias Yang Berpotensi Meningkatkan Pendapatan Masyarakat," J. Mar. Kreat., vol. 2, no. 1, pp. 44-49, 2020, doi: 10.35308/.v2i1.2274.

[9] N. To'bungan, "Pengaruh Perbedaan Jenis Pakan Alami Jentik Nyamuk, Cacing Darah (Larva Chironomus sp.) dan Moina sp. terhadap Pertumbuhan Ikan Cupang (Betta splendens)," Biota, vol. 1, no. 3, pp. 111-116, 2016. 